\title{
Rethinking agency: persons and things in the heterotopia of 'traditional Indian craft'
}

\author{
Soumhy Venkatesan University of Manchester
}

\begin{abstract}
Based on ethnography among handloom mat-weavers in South India, this article asks how persons and things become agents, and what this process involves. Foucault's concept of the heterotopia is utilized to think through the puzzle seen in 'traditional Indian craft', but not restricted to it: why and how are certain marginalized persons and things brought by powerful others to the centre of a framed social space? How does this repositioning simultaneously enhance and constrain the capacity of these persons and things to act effectively? The article also proposes a way of thinking about acting things while avoiding the problem of intentionality.
\end{abstract}

This article rethinks agency, here defined, following Gell (1998), as the capacity of persons (and things) to act in such a way as to cause or direct the course of events in a social milieu. It suggests that we interrogate the contexts within which persons (and things), especially those who are normally marginalized and powerless, find themselves able to act effectively. This focus enables an understanding of how the capacity for agency might hinge on accepting and performing figurations imposed by powerful others.

I will explore the above by focusing on 'traditional Indian craft', an important category in colonial and post-colonial India that will be discussed in more detail below. My ethnographic focus will be Muslim mat-weavers in a Tamil town, Pattamadai, who have, since the middle of the twentieth century, been identified by powerful state and non-state elites as traditional craft producers on the basis of the very fine mats that they weave. The interactions between the mat-weavers, the objects they make, and elites in India point to inequality, hierarchy, unequal access to resources, and the consequent strategic practices on the part of the marginalized. I would, however, like to concentrate in particular on one remarkable aspect of this ethnography: the deliberate bringing by powerful elites of marginalized people and things to the centre of a social space (here, traditional Indian craft), re-creating them as valued objects of attention. I employ the concept of the heterotopia (Foucault 1986 [1967]) to explore this aspect. Foucault defines the heterotopia as a space in which to socially realize utopia, which is an 'imagined perfect place or state of things' $(O E D)$. My own focus is on the way in which 
utopian visions are articulated and sustained through social practices, and how this process points to questions of power and agency.

Certain utopian visions that arose in late nineteenth- and early twentieth-century India as a reaction to growing industrialization have meant that selected hand-made things have come to be highly valued in some circles in elite urban India. Identified as 'traditional Indian craft objects', these things are brought into relationship with other things, persons, and ideas that inhabit the social space of traditional Indian craft. Traditional Indian craft objects access, and act in, spaces that are normally barred to their rural-dwelling, poor, and generally marginalized producers. Even though their makers, consequently re-classified as traditional craft producers, also enter this space and acquire the capacity to act within it, they do so because of their manufactures. Association within the social space of traditional Indian craft gives makers agency, but it also burdens them. Makers are positioned in ways that abstract them from their larger social contexts. A personhood (that of craft producer) is posited for them. This personhood has to be learned and performed.

Notwithstanding the fact that selected hand-made things and their producers are key, the idea of traditional Indian craft originates from a disparate grouping of influential people, including politicians, thinkers, members of development organizations, and other urban elites. I refer to this grouping as the craft world. ${ }^{1}$ The interests that members of the craft world have in Indian craft are varied, even contradictory. What they all profess is a strong vision of craft as a way of resolving social problems that concern them, and the will and power to try to realize their ideals. While influential non-state actors in the craft world may be high caste, they are almost always high class with a history of support for culture, or wealthy and well connected. Many are female. Indeed, a side-effect of actively supporting traditional craft through membership in certain NGOs is that it can open access to some elite circles in India. Likewise, those poor rural producers who are supported as craft producers also gain access to these elite circles. What they can then do is a different matter, as will be seen.

Analysing traditional Indian craft as a heterotopia enables an understanding of the particular ways in which relations between people, things, and processes are set up and contrasted to the 'problems' that the utopian visions seek to address. This allows an exploration of agency and power. As a heterotopia, traditional Indian craft may be compared with similar situations around the world wherein marginal people are made central to a project in line with certain utopian visions, and thereby partially objectified by powerful others. Examples includes the efforts of non-state agencies to protect 'primitive peoples' and pristine habitats, or markets for 'folk' or 'ethnic' art, or the celebration of women within some nationalist discourses.

\section{Traditional Indian craft}

The term 'craft', as used today, first arose in eighteenth-century Britain, gaining momentum in the nineteenth century, and travelling to different parts of the world, including India. Greenhalgh (1997) identifies three distinct sets of concerns that were brought together in the nineteenth century by thinkers in Britain, some of whom went on to be influential in the Arts and Crafts Movement. These are the vernacular, the decorative arts, and the politics of work.

Greenhalgh traces how growing unease with industrialization led to the valorization of the vernacular: village life, the work of country craftsmen, and the 'authentic' tradition. At the same time the decorative arts or art that fulfilled a function (such as 
fine weaving, ivory-carving, and gem-setting) were being detached from the increasingly exclusive category of fine arts ('art for arts' sake'). Although the products of country craftsmen and luxurious decorative things had little in common, they were both hand-made by skilled artisans who often had control over the entire production process. What linked them, then, was another key area of economic and political concern: work.

Resistance to mechanical and political control of the worker went back to the origins of the Industrial Revolution. Key nineteenth-century figures, in particular John Ruskin and William Morris, sought to highlight the alienation of the worker with the onset of the machine age, in the process romanticizing non-industrial work.

The decorative arts, the vernacular tradition, and the politics of work were brought together in the nineteenth century to form the term 'craft'. They did not necessarily belong together, but, 'the historical moment was right, the combination in this context dynamic and compelling' (Greenhalgh 1997: 35). The politics of work provided craft with its moral core. Vernacularism gave craft its nostalgic and nationalistic character. The inclusion of the decorative arts made craft a matter of elite concern and consumption.

Indian artisanal products aroused much interest in Britain from the mid-nineteenth century. India, with its 'living traditions of craftsmanship', became one of the utopias of the Arts and Crafts Movement (Mitter 1994). Prominent designers and thinkers in Britain, including William Morris, took up the cause of the preservation and protection of Indian artisans from industrialization. In India, the ideas of the Arts and Crafts Movement were taken up and built on by, among others, George Birdwood, ${ }^{2}$ Ananda Coomaraswamy, and E.B. Havell.

Ananda Coomaraswamy characterized craft in India as a 'sacred mystery, a sacrament [rather] than a secular trade' (1909: 72-3). Coomaraswamy's Indian craftsman upholds the order of things with little concern for financial gain. His work is a 'calling', something greater than himself. Coomaraswamy explicitly contrasted what he saw as the individualistic thrust of art in the West to the socially meaningful character of art/craft in India (see Chattopadhyay 1980: 55). For him, Indian craft was timeless, materializing, not an individual's vision but a community's, indeed an entire nation's. Nature and culture came together in his vision of craft. $^{3}$

In the nineteenth and early twentieth centuries, less salubrious aspects of village life were ignored, as were the more mundane realities and aspirations of actual producers' lives. These were submerged under the notions of crisis under colonial rule, and the urgently felt need for preservation and support, whether through the colonial state or in other ways. For some, like Havell (1986 [1912]), the destruction of India's traditional crafts was a destruction of an Indian identity itself. This view allied certain visions of craft to the nationalist project. Goswami (2004) points out that the nationalist movement in India, as elsewhere, sought to engage both with the universal ('everyone has/desires a nation') and with the particular ('we are a nation because we share certain things in common which make us unique'). India's craft heritage came to be held up as an example of the latter.

There was clearly something extremely aesthetically appealing in the ways in which the thinkers about craft, despite their distinctive views, described craft objects, producers, and the contexts of production. Their romanticizations were to endure, and inform efforts to preserve, promote, and develop selected Indian manufactures. Coomaraswamy, for instance, is frequently invoked in contemporary writing on craft. The 
particular objects that were identified as craft objects also enchanted. Modified under the rubric of revival, craft objects were, and are, made to appeal to elite tastes. Equally enchanting was the technology of production - the transformation, through simple technologies and embodied skills, of often unprepossessing raw materials into shimmering fabrics, elaborately carved furniture, or other finely wrought objects.

The politics of work was to reach a wider and more politicized sphere. Ruskin's essay 'Unto this last' (1987 [1862]) deeply influenced Gandhi's thinking on politics and the economy. Gandhi came to believe 'that a life of labour, i.e. the life of the tiller of the soil and the handicraftsman, is the life worth living' (cited in Brantlinger 1996: 467, my emphasis). ${ }^{4}$ Ruskin's work also confirmed his anti-industrial stance, which found its most elaborated form in his celebration of hand-spun hand-woven cloth (khadi). Tarlo discusses Gandhi's belief that

\footnotetext{
[t]hrough stimulating the production and use of indigenous cloth he could provide supplementary employment to the masses, remove untouchability, promote the self-sufficiency of India's villages, weld together people of all religions and castes, drive out British rule by non-violent means and introduce an improved standard of morality and sense of national unity. Khadi and spinning were to become not only the unifying national cause in the peaceful struggle for freedom but also the basis of a new non-industrial, craft-based economic structure in independent India (1996: 87).
}

In early twentieth-century India, then, are found a set of utopian ideas and actions around pre-industrial material culture: the idealization of the producer and production process, the valorization of the craft or village manufacture, and the location of the 'real India' in its villages and craft heritage. These ideas, while not entirely harmonious, stemmed from the belief held by several influential and powerful elites that industrialization was both increasing general wretchedness and/or destroying something beautiful that had existed since ancient times. For many of these thinkers, the destruction of craft resulted as much from colonial policies and practices as from industrialization. ${ }^{5}$

Industrialization was nevertheless a priority in a newly independent India. But neither decorative crafts nor khadi was abandoned - both meant too much ideologically and politically. The two, however, began to separate. The decorative arts came to hold centre-stage within the category of craft, while khadi moved into the category of village industries, politicized though unromanticized. Its lasting legacy to the new category of craft was the moral legitimacy that its advocacy by Gandhi had engendered, along with the notion of the village community that required protection. Traditional Indian craft continues to be frequently mobilized within the nation-building project. Beyond India, too, craft is an important element in the way the nation presents itself. ${ }^{6}$ A Government of India brochure declares: 'There is nothing so Indian as Indian Handicrafts' (cited in Durrans 1982: 19). Crafts are seen as quintessentially Indian, regional variations and local particularities are co-opted into the motif of unity in diversity; craft objects are seen to embody the continuity of the Indian nation in time and space.

The inexorable thrust of industrialization and urbanization in contemporary India continues to occasion distress to some (usually urban elites) who believe, as Havell did almost a century ago (1986 [1912]: 5, 9), that India's development lies not in 'slavishly industrializing' but in being sensitive to its artistic and manufacturing traditions and in working with its hundreds of thousands of craft producers. India's cities continue to burgeon. Skilled artisans continue (by choice or necessity) to find other kinds of work. 
This tendency has given rise to several Indian non-governmental agencies that seek to reposition craft as vital rather than marginal (e.g. the Craft Council of India, the Madras Craft Foundation). In this strategy, they are sometimes assisted by the state, with its own economic, political, and ideological commitment to craft.

The craft sector is important for its income generation potential, especially in rural India, accounting for between 3 and 6 per cent of employment and GDP in the 1990s (Liebl \& Roy 2003). State and non-state actors see craft development as a way to increase rural employment in the non-formal sectors, thereby stemming the tide of rural-urban migration. ${ }^{7}$ As an important source of foreign exchange (Liebl \& Roy 2003), the craft sector and especially those producers who manufacture exportable objects are a significant focus of state attention.

Traditional Indian craft (and the objects with which it concerns itself) is an abstraction based on selective and partial reassemblings from a more fragmented and chaotic whole. Without the unifying idea of craft, there are blacksmiths, weavers, woodworkers, and so on. Their work does not occasion national and international concern. However, when identified as crafts, the thing and the idealized context of production re-define producers as craft producers who are likewise rendered enchanting, and objectified.

There are now between 10 and 20 million 'official' craft producers in India. ${ }^{8}$ This identification has economic and social consequences, especially in opening up the producers and their objects to development initiatives, to visibility within the nation, to new markets, and in bringing them through the things they make into relations with elites. For most rural, marginal, and financially insecure producers, their inclusion within the category of traditional craft can be life-changing. This is why it is imperative to understand the constitution of the social space wherein marginalized people and things are re-created as emblems and acquire a measure of agency. I suggest that traditional Indian craft is not unique in this regard, and that the concept of heterotopia allows us to make comparisons with similar projects elsewhere.

\section{Traditional Indian craft as heterotopia}

Thomas More, who coined the term in the sixteenth century, specifically saw the utopia as a place that did not exist. Others following him, however, sought to realize their utopian visions for an alternative, better world, so that 'gradually over the 19th century, these "desirable regions of the mind" developed further into "ideological blueprints" , (Symons 2007: 12). Foucault went further to suggest that

\footnotetext{
[t] here are probably ... in every culture, in every civilization, real places ... which are something like counter-sites, a kind of effectively enacted utopia in which the real sites, all the other real sites that can be found within the culture are simultaneously represented, contested and inverted (1986 [1967]: 24).
}

This is the heterotopia. Below is a detailed discussion of its principles, understood through the example of Indian craft.

The heterotopia is historically constituted. A given society at different historical moments can make the same heterotopia function in very different fashions. Further, heterotopias 'have a function in relation to all the space that remains' (Foucault 1986 [1967]: 27). The role of the heterotopia might be either to create a space that exposes the illusory nature of other spaces of everyday human life or to create another real space that is 'perfect' in comparison to the messy, jumbled spaces of our lives. In India, an idealized and romanticized craft context was discursively produced and explicitly 
contrasted with the ruptures, distress, and inequalities seen as resulting from industrialization, colonialization, and modernization. Indeed, over the decades, craft has been opposed to concerns that have changed over time. As I showed, initially inspired by resistance to industrialization, the category of craft was then mobilized within nationalist projects that were also ambivalent about industrialization. In independent India, craft has become a way of preserving the nation's material heritage, connecting past to present and furthering the developmental agenda of the state and the public sphere.

Another important characteristic of the heterotopia is that it is 'capable of juxtaposing in a single real place several spaces, several sites that are in themselves incompatible' (Foucault 1986 [1967]: 25). The heterotopia of craft is simultaneously concerned with the market and identified as a 'sacred mystery' (Coomaraswamy 1909: 72), with hereditary producers, with attempting to find income-generation schemes for groups identified as disadvantaged; it can be about luxurious sumptuary practices and be taken up as ethical consumption; and it can be, as one patron described, 'both contemporary and timeless'. Heterotopias not only juxtapose diverse sites and concerns, they also collapse time, bringing into one single narrative different times and spaces.

But who is in the social space that is identified as a heterotopia, and who manages it? For Foucault, heterotopias 'always presuppose a system of opening and closing that both isolates them and makes them penetrable' (1986 [1967]: 26). The heterotopia has its own forms of barriers and gate-keeping. Even when a heterotopia looks open to anyone, it is not. Throughout the history of the term in India, craft has been the province of socially, economically, and politically powerful people. Particular objects are identified as traditional craft products by members of the craft world, and then their makers as traditional craft producers. It is no accident that the craft producer has not yet made a personal appearance in this article. Presented as victim or as symbol, valued for his products, the craft producer is spoken for, rather than speaking. His entry into and position within the heterotopia are highly managed.

The heterotopia of traditional Indian craft specifies utopian and ideologically driven relations between persons and things that are abstracted from other social spaces and associated (Latour 2005) in specific ways. Heterotopias and the social categories that arise from them actively create agents and also particular types or workings of agency. The heterotopia is coeval, yet not coterminous, with other social spaces. It is a fruitful investigative context to trace ways in which connections are made, entities are associated, and agents emerge, even as power relations are conserved.

The next section grounds the above by narrowing the focus to a group of Muslim mat-weavers who have been identified as traditional craft producers since the middle of the twentieth century on the basis of the mats they weave.

\section{Creating a 'craft community': the mat-weavers of Pattamadai}

Pattamadai is a town of around 13,000 people in Tamilnadu, South India. The Labbais are a Tamil Muslim sub-group and number, in Pattamadai, around 650. The Labbais of Pattamadai say that since the end of the nineteenth century they have manufactured from locally growing reeds extremely fine mats that have a texture like silk.

As objects made by hand from start to finish, exclusively by one sub-group of Muslims all living in the same town and claiming kinship with each other, Pattamadai mats seem well placed to be seen as craft objects that embody the intentions and essence of their makers and are inalienable from them. But it takes more than that to be part of the heterotopia of craft. 
In 1953 V.A.K Rangan (henceforth V.A.K.R), a chief agent of the Royal Insurance Company in Madras city, decided to mark the coronation of Queen Elizabeth II by making her an unusual gift. He commissioned a mat from the weavers of Pattamadai, and specified that they weave into it the recipient's and gift-giver's names. The mat would embody the connection V.A.K.R sought to make with the Queen. But coronation protocol did not allow individuals to make gifts to the Queen. V.A.K.R had somehow to make the mat look like it was a gift from the weavers to the Queen without erasing himself. Figure 1 shows the final form taken by the mat.

The mat never got to the Queen, having failed to pass through the elaborate gifting protocol. ${ }^{9}$ But it, along with other gifts meant for the coronation, was seen by Kamaladevi Chattopadhyay, an influential supporter of craft and head of the All India Handicrafts Board. It was then that 'the Handicrafts Board became alive to the existence of the craft' (Nambiar 1964: 4). This was a turning-point.

Chattopadhyay went to Pattamadai. She encouraged the weavers to organize themselves into a handicrafts co-operative society, to which was dispensed government aid, including new looms and money and land for the co-operative society. Pattamadai mats were now craft objects and the Labbais a craft community. Support for the newly

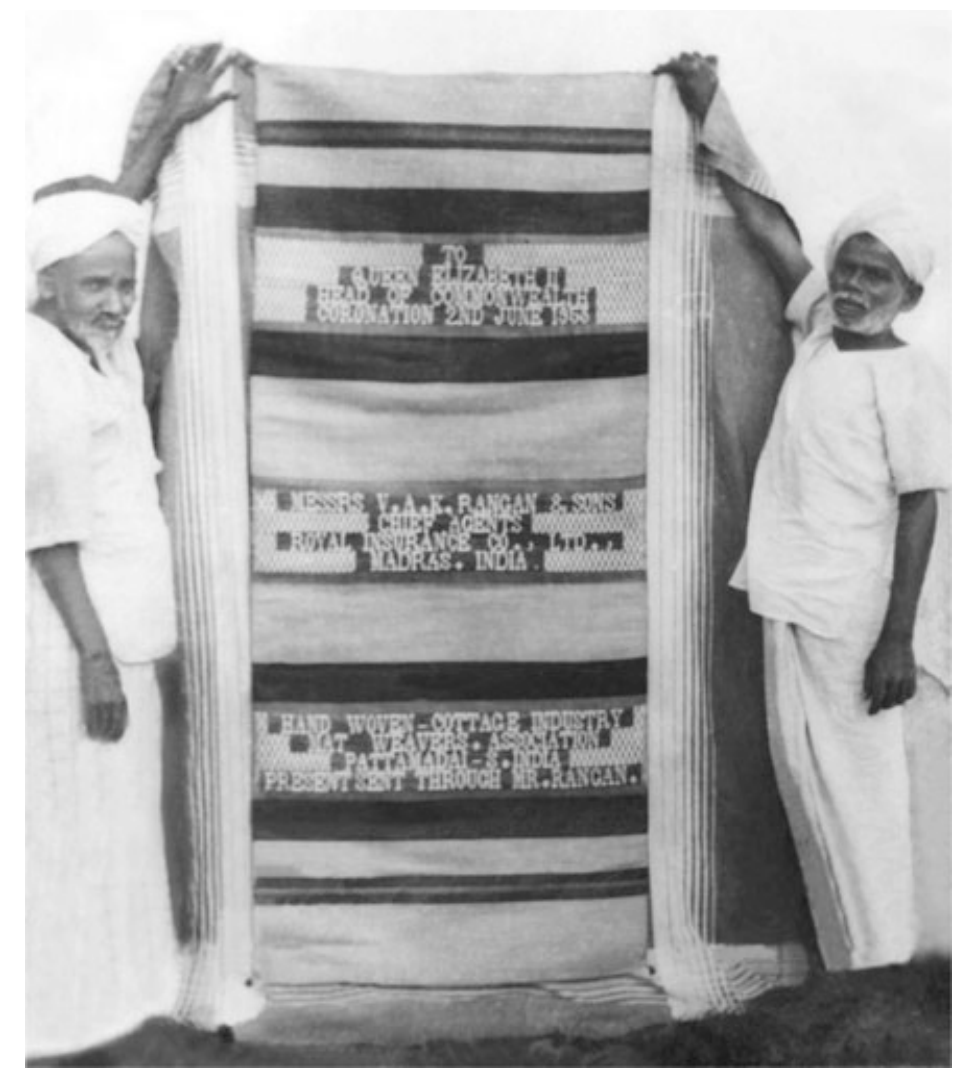

Figure 1. The mat for the Queen. (The original of this photograph is held by the Pattamadai fine mat-weavers' co-operative society. The office-bearers have kindly granted me permission to reproduce it in my work.) 
recognized craft came in the form of commissions for more mats to be used in gifting, invitations to craft markets, and even gifts of land for weavers to build houses. Non-governmental organizations seeking to develop craft also started to work with the weavers, bringing more resources and markets in their wake. Pattamadai mats and their makers were grouped with other craft objects and craft producers from different parts of the country, finding a place in the heterotopia.

\begin{abstract}
In the metamorphosis of the green korai growing wild on the banks of the Tamaraparani, into the wonder that is the Pattamadai mat lies the genius of the paramparic [traditional] Indian craftsman. His conceptual harmony which so effortlessly weaves function and aesthetics together into objects of superb craftsmanship, his empathy with the moods and rhythms of nature, from which much of his work is crafted, as well as total dedication to his calling spells the very essence of India's craft heritage, be it the minakari and jadau jewellery of Jaipur, the namdahs and carpets of Kashmir, the shola pith craft of Bengal or the stone carving of Karnataka. Or the serene allure and brilliant workmanship of the fine Pattamadai mat (Chari 1996: 15).
\end{abstract}

Here the Labbais of Pattamadai, as craft producers, are associated with high-caste jewellers and stone-carvers, and high-status Muslim carpet-makers. What unites them is the relationship they are seen to have with their 'calling', and their manufacture of things that are valued by elites.

\title{
Acting things and persons
}

For Gell, agency is the capacity to effect changes in the causal milieu. This capacity is not restricted to human beings. 'Whenever an event is believed to happen because of an "intention" lodged in the person or thing which initiates the causal sequence, that is an instance of agency' (Gell 1998: 17). Gell further suggests that in their exercise of agency persons and things can be seen as theoretically equivalent. This is a liberating observation, but needs refinement, as Gell himself recognizes.

Agents cause events. However, while persons are always (ideally) agents, things (material, tangible, visible objects) are only agentive within certain contexts. This is one criterion that distinguishes primary agents or persons from secondary agents or things (Gell 1998: 17). The other, more problematic aspect of Gell's definition is intentionality. People can and do materialize their intentions and use things to further their ability to act in the world. However, it is not always the case that they or others on whom these things act attribute intentionality to the things themselves.

Both persons and things cause events to happen in the Indian craft context. Indeed, in some cases things are far more effective than persons. Craft objects can access spaces that their producers cannot. They thus act directly in more contexts, distributing the effectiveness of not only their makers, but also others through whose hands they pass. The Muslim mat-weavers certainly recognize that the mat for the Queen caused things to happen to them, but they do not attribute any intentionality to it.

Indeed, the central position accorded to intentionality within Gell's definition whether as something inherent or something attributed - causes something of a problem. We might need a different conceptual vocabulary to take on board the capacities of persons or things to direct the course of action. We might also need to take into account unintended actions. This is where Latour's distinction between 'mediators' and intermediaries becomes useful (2005: 37-42).

Latour's intermediary transports meaning or force without transformation. Defining the inputs of the intermediary defines its outputs. It is 'a black box counting for one; 
even if it is internally made up of many parts' (2005: 39). The computer on which I typed up this article is an intermediary. With mediators, on the other hand,

[t]heir input is never a good prediction of their output; their specificity has to be taken into account every single time. Mediators transform, translate, distort, and modify the meanings they are supposed to carry ... No matter how simple a mediator may look, it may become complex; it may lead in multiple directions (2005: 39, original emphasis).

While intermediaries may be forgotten, mediators may not. To return to the computer, when it breaks down it may become 'a horrendously complicated mediator'. So may a 'banal conversation [become] a terribly complex chain of mediators where passions, opinions, and attitudes bifurcate at every turn' (2005: 39). Mediators can be things, conversations, persons, letters, anything at all.

Latour's discussion of mediators allows us to recognize things as causally active without attributing intentionality to them. A mediator (however much it may distort or transform situations or create new possibilities) does not need to, or be seen to, possess intentionality. Furthermore, actors (things or persons) can be seen to move between the two states of mediator or intermediary. Finally, we might ask about the figuration of agency (Latour 2005): that is to say, what is recognized as having caused something, and how does this figuration work according to who is telling the tale and when?

The mat for the Queen is best seen as a mediator. Initially embodying V.A.K.R's intentions and his desire to create a connection between himself and an inaccessible and distant personage, it instead created other connections, most unforeseen. Rather than be, as was intended by V.A.K.R, a mediator that would transform him into someone with a connection to the Queen, it became a mediator in relation to the weavers, transforming them into craft producers. V.A.K.R became an invisible intermediary even as the mat he commissioned made the weavers visible to the powerful and sympathetic head of the national craft development board and, after that, to the rest of the nation. The mat was transformative, as is recognized widely. Though lost now, it is still invoked:

No lore concerning the [Pattamadai] mat would be complete without its faery touch - way back in 1948 [sic], out of the wealth of India's handicrafts, it was a finely textured Pattamadai mat which was chosen as India's wedding gift [sic] to the then Princess Elizabeth (Chari 1996: 15, my emphasis).

What does it matter that the gift that never got to its destination or that the details above are fantastic? The mat for the Queen transformed the weavers from poor rural mat makers to traditional Indian craft producers, and continues to keep them visible.

\section{Weavers and their work}

My early interest in the weavers was sparked by a Pattamadai mat that I found beautiful. It was the object, then, that first brought me to the makers. This attitude is not unlike that of many members of the craft world, to whom I am not socially dissimilar. But, months of sitting in weavers' homes watching them weave and talking about work, money, backache, worries, and aspirations soon dispelled any vestigial romanticism about mat-weaving. ${ }^{10}$

Most Pattamadai Labbais are ambivalent about mat-weaving. Weavers and nonweavers from the group refer to it as their 'traditional occupation' (paramparai thozhil) 
when speaking to interested outsiders. It is common to hear comments such as 'nowhere else in India will you find mats like these'. But that does not mean people want to weave, or at least not all the time. I observed, and was frequently told, that 'those with means' rarely took up mat-weaving; also, when a household had enough income from other sources, weaving would be abandoned.

Many weavers describe mat-weaving as 'difficult work' (kashtamana velai), which adversely affects the eyes and the back. The Vice-President of the Fine Mat-Weavers' Handicrafts Society claimed that 'poverty and patience' (varumaiyum porumaiyum) were the two essential qualities of a mat-weaver: only a poor person would weave. He himself, like the other main office-bearers of the co-operative society, does not. Educated males rarely weave, nor do those brought up in relatively comfortable financial circumstances. A weaver said of her brother, 'He is educated, why should he do this work?' One weaver told me that she had had no need to weave in her father's house: he was a government employee and the children and women of the household did not need to earn money. It was only after her marriage, when finances were tight, that she took up weaving.

At the same time, people recognize that household industry, including mat-weaving, unlike wage labour, allows a certain degree of freedom, even if it does not bring much money. One works to one's own time, in one's own home, and can step up or down production as necessary. This is particularly important for females, who are tied to domestic tasks, but also need to earn money.

Two kinds of mat are woven in Pattamadai - 'fine' and 'super-fine'. These take over a week and up to a month, respectively, to produce. This is reflected in the high price of Pattamadai mats relative to coarse mats produced elsewhere in Tamilnadu, which are not considered craft objects. Weavers cannot afford not to sell their mats. Even if they could afford to keep them, they find them too slippery for the uses to which they put coarser mats - spreading them on the floor as seating and bedding. As the weavers do not use the mats, they must be able to sell them, or there would be little point in making them. This is where craft becomes important. But most weavers in Pattamadai do not directly engage with the heterotopia of craft. They weave, leaving traders to sell their mats in whatever way seems best.

Traders and NGOs take pains to emphasize that Pattamadai mats made by Muslims are bought by high-caste and high-class Tamil Hindus for use during weddings. This is true of the fine rather than the super-fine mats, but it allows the discursive re-creation of all Pattamadai mats as embodiments of the liberal ideal of harmony between Hindus and Muslims. New craft markets have opened up for super-fine mats on the back of this (see Venkatesan in press: chap. 7). That well-off Tamil Muslims also buy fine mats for use during the nikaah (or marriage ceremony) is rarely mentioned in serious speech acts - it has little currency among people who believe that craft did, and can continue to, unite disparate groups.

Some weavers expend much time, energy and enthusiasm on their mats, especially when they feel that they are making something special. But they, and most others, simultaneously resent being tied to the loom with few other choices and yearn to be doing something, anything, else. Local mat-traders and NGOs who sell mats in distant markets often have to cajole even those who weave to produce mats regularly. People, men especially, drop in and out of weaving, taking up petty trading or migrant work. None of this is visible in the discourses about craft, where craft producers who take up other work are seen as victims of modernization requiring assistance. 


\section{Being agentive within the heterotopia}

It is not easy to trace the origin of Pattamadai silk mats, a real work of aesthetics rather than the vision of the mat-weaver.

Muthahar 1995

The Labbais of Pattamadai are fairly powerless within the Indian nation - living in semi-urban India, they are members of a low-status Muslim group, financially insecure, own few assets, and are engaged in the informal sectors of the economy. Within the larger nation they have neither economic nor social capital, except as traditional craft producers. Their identification as craft producers makes them national objects of attention. This makes them and the things they make able to act in the larger social world. Both mats and weavers acquire agency. But what exactly does this mean?

Anthropologists, as champions of the voiceless or powerless, often seem to look for agency, especially on the part of people who seem to have none. However, agency is a problematic analytic because it is only recognizable after the fact. It foregrounds effectiveness of action (Laidlaw 2002). Gell (1998) agrees that one only knows that agency has been exercised when something has changed in the causal milieu. I would add that uncritically accepting agency as a good thing elides the kinds of compromises that its exercise may involve. For Saba Mahmood (2001), agency is the capacity to act within historical relations of power. Following her, if we accept that the exercise of social agency is only possible by persons and things that are part of social relations and brought into social networks, we have to interrogate the contexts within which particular things and persons find themselves able to effect changes in the social world. The following discussion shows how agency accrues to those craft producers who accept the aesthetic judgements, kinds of personhood, and ideological orientations specified for them by powerful others who manage the heterotopia.

The national awards competition was instituted in 1965 by the government of India. National awards are given to outstanding or master craft producers in recognition of their excellence in craftsmanship and invaluable contribution to Indian handicrafts and handlooms' (GOI 1999: 7).

Makers or their sponsors submit pieces to the annual competitions. 'Eminent experts in the field of Handloom and Handicrafts' ${ }^{11}$ are expected to select around forty 'masterpieces' from the 1,500 or so objects submitted from different parts of the country. A member of the committee described the process of judging:

\footnotetext{
All of us are in this room where the objects are displayed. Everyone is just walking around. We want to finish and go home. Someone who knows [about a particular object] says something about it - what it is about, how long it would have taken to make. We look at the piece more closely (9 March 200o).
}

The makers of the 'masterpieces' receive, from the President of India, a cash prize and a copper plaque; they are also titled 'master craftspersons'. Preference is given to national award-winners for participation in national and international craft events, thereby opening up awareness of, and markets for, their craft form. Members of the local and national press interview award-winners. They become the public face of their craft industry.

But, in addition to producing a 'masterpiece', the master craftsperson should be 'a social leader and an important entity in the community' (Chattopadhyay 1980:12; also GOI 1998: 
127). Judges are encouraged to pay special consideration to 'languishing crafts' or crafts that would benefit from the kind of visibility that a national award brings. Even though it is accepted that an individual benefits from the award, the idea is that recognition for one individual will help every member of a 'craft community' (see Venkatesan 2006).

In 1992, a mat-weaver whom I shall call Beevi won a national award. ${ }^{12}$ Anamika, a member of an important industrial family and a prominent member of several important craft development agencies, was responsible for sending the award-winning mat to the national awards competitions. She said:

\footnotetext{
One person from Pattamadai, Mantri, was well known to [our NGO]. He used to come around Madras with mats made in Pattamadai. This is when we saw him ... We used to invite him to bazaars and exhibitions held by the NGO. Sometimes, Mantri would be accompanied to these events by his daughter, Beevi. He always described her as a very good weaver and said that she was the only person making the highest quality of mats woven in Pattamadai. When the NGO decided to sponsor a Pattamadai mat at the national awards competition, I asked Beevi to weave a super-fine mat. [I] specified the designs and colours to be used in this mat. However, when the mat arrived, it was far from perfect and there was no time to get her to weave another mat. In the end, I just picked up a Pattamadai mat that was in my house and sent it to the competition. Beevi had probably also woven that mat (December 1999).
}

It was this mat that won Beevi the national award.

Two things stand out in this description. Firstly, while Beevi was the person chosen to weave the mat, she was not expected to make any choices about colours or designs, Anamika deeming herself more knowledgeable. Secondly, when the mat arrived, it was judged as sub-standard. Another mat - one more accurately reflecting Anamika's aesthetic concerns and, as was subsequently made clear, the competition judges' - was substituted for it. ${ }^{13}$ The substituted mat was also almost certainly made by Beevi, but it was not the mat that Beevi had chosen to submit.

It is noteworthy that when Anamika described the submission of the mat and gave me permission to write about it, she did not seem to have any doubts about her decision to substitute mats. To her mind she was right: the substituted mat did win the award. Anamika was concerned with the preservation of the craft and felt that a national award would be good not merely for the individual who won it but also for the whole mat-weaving industry. A national award would, and did, transform the Pattamadai mat-weaving industry. This is why the mat that was submitted had to be the one best placed to win, not the one specially woven by the weaver, who in any case was only following very precise directions. We come up here against a hierarchy that sees producers as skilled makers, and members of the craft world as knowledgeable directors. The producer, who in accepting directions implicitly accepts her characterization as 'merely' skilled, can do well out of this.

Neither Mantri nor Beevi ever told me that the mat they had submitted was not the one that had won the award. Perhaps it did not seem worthy of mention (nor could I find the words to raise it with them). The successful mat indexed Anamika's agency, and in doing so extended Mantri's and Beevi's. One might speculate that rather than the specific mat, it was the outcomes its success brought that were important. One of these outcomes was the gift of a plot of land made by the government to Beevi.

Shortly after Beevi's national award, a new craft development NGO came to work in Pattamadai. Anamika was a key member of this NGO, which initially worked with Mantri, but later extended its work to other weavers in Pattamadai. The NGO took up as one of its first projects the introduction of natural dyes to the weavers and organized a workshop. 
Most weavers prefer chemical dyes both for their ease of use and their bright colours. Few weavers attended the workshop, but one, Ali, was enthusiastic. Ali later submitted to the national awards competition a mat he had woven using natural dyes. His timing was good, coinciding with a larger thrust to revive the use of natural dyes in craft practice. His mat found favour, and he won a national award. ${ }^{14}$ There were now two award-winners in Pattamadai, and they came into direct competition with each other over access to resources from the state and other powerful persons in the craft world.

\section{Asking effectively}

In 1996, Beevi sent a letter in English to the Chief Minister of Tamilnadu, requesting him to 'save the centuries-old mat-weaving industry of Pattamadai'. The letter identifies the writer as belonging to a 'minority community' [Muslim] and as coming from 'a very poor family of Lebbais' sustained by 'my father [who] is aged' and 'managing the family with his meagre income [from] a mat shop in the village'.

Mat-weaving is described as 'our hereditary craft', but 'at present the industry is not prospering now only a few families are engaged in this craft with great difficulty'. The writer contrasts the demand for the mats from 'several distinguished visitors from all over India and abroad' with the position of the weavers, who are 'poor Muslim Lebbais working hard day and night to earn their meagre livelihood and to preserve the industry for the future'.

Identifying herself 'with humility and reasonable pride' as a national and state award-winner for fine mat-weaving, the writer lists her personal contribution to 'the growth of the crafts' as an instructor in two government-sponsored training schemes for youngsters to learn mat-weaving. Finally, she makes two requests, based on the addressee's 'proverbial sympathy to people like me, who are in indigent circumstances'. The first is for monetary assistance to build a house on the plot of land allocated to her by the government. The second is for monetary assistance to set up a training shed 'so that the age-old cottage industry could be preserved'.

The language throughout the letter is flowery. It reiterates the state of helplessness of the writer and all the other craftspersons in the village for whom she speaks. Yet it is only for herself that she requests a house; the training shed, too, would primarily benefit her father's business as he could claim ownership over any mat woven on the premises.

The letter-writer has clearly grasped how to present herself as a craft producer. The letter resonates with the way in which the heterotopia is visualized and functions. Beevi presents herself as someone who is struggling to preserve an age-old industry for the sake of future generations. The passage of time and its ravages can be halted through supporting the craft producer, and thereby the objects she makes. Here, the heterotopia's relationship with time is played on: centuries-old objects and skills are in danger in a modern world and need support. ${ }^{15}$ There is also an implication of selflessness in the face of the larger goal of preserving the mat-weaving industry. This conforms to the characterization of craft producers as helpless individuals struggling both to retain their identity and to prevent the loss of an aspect of national heritage. The need for protecting and supporting the mat-weaving industry is strengthened by the claim that distinguished Indians and foreigners have appreciated the mats. Not only the artisans, but also knowledgeable and powerful others, believe that the craft industry is important. Finally, the letter draws attention to the fact that Beevi has won national and state awards. Her mats have been recognized by the craft worlds as masterpieces. She has successfully entered the heterotopia and asserts her claim to be listened to, and assisted. 
The letter's authorship is noteworthy. Beevi, in whose name it was sent, had little to do with it. Her father, Mantri, was the driving force. Equally, the situation is not as simple as portrayed. Mantri is the town's leading mat-trader and a prime beneficiary of craft development. Far from suffering from the 'extinction of the centuries-old craft of mat-weaving', he spends significant amounts of time ensuring that he has enough stock for the various exhibitions and bazaars to which Beevi is invited. He can even afford to turn down orders. Yet, because they are primarily involved in the informal sectors of the economy, it is not easy for him or Beevi to obtain a large enough bank loan to build a house and a weaving shed. The only way to raise money is by appealing to their membership in the category of craft. Mantri was particularly keen to secure Beevi's future as she has no husband or children; he worried about what would happen to her after his death.

The contrast with Ali's attempt to secure a house cannot be more striking. Shortly after winning the award, Ali got his daughter married at great expense. This put them in debt and they had to sell their house. He, his wife and children moved into a rented house in a lower-caste section of Pattamadai. He told me: 'I wrote a letter to the government and said that it was not correct that a national award-winner should live in this part of the town. I requested them to allocate land for a house. ${ }^{16}$ Nothing came of this request. Ali then requested Anamika to give him a loan of Rs. 50,000, offering his award plaque as surety. Perhaps he saw the trophy as providing tangible evidence of his skill as a weaver and his personal recognition by the state as a master craft producer. Again he met with no success. In both cases Ali was acting against the spirit of traditional Indian craft. In the first instance, instead of emphasizing his position as a member of a marginalized social group who was making valued objects and thereby doing something of national importance, Ali expressed his belief that, as an award-winner, he was entitled to a better life. In the second instance, he equated his award with money. Furthermore, ignoring the type of personhood specified for craft producers, he incorporated the award into his personal biography without any reference to the larger principles that the craft producer and the craft object are supposed to embody. Ali apparently believed that his recognition as a master craft producer meant that he would be valued without his constantly having to reiterate his commitment to craft or to producing craft objects. He failed to recognize, notwithstanding the national award, that it was the things he made that made him valued, and that he was better off presenting himself, like Beevi, in ways that accorded to the vision and relations specified within the heterotopia.

In 2000-1, Ali was living in a rented house. He was weaving and selling his mats, and mats that he would buy/commission from other weavers, at craft bazaars. Later, he gave up all work with mats and set up a tea stall in a nearby town. He had fallen fully out of the heterotopia. The irony is that Ali, when he did weave, was genuinely excited about weaving and keen to try new things, experiment and innovate with new textures and colours; but he was simply not willing or able to present himself in ways that would be effective within the heterotopia. In the same period, Beevi and Mantri had secured money in the form of loans and grants to build both a house and a training shed. ${ }^{17}$ Mantri, with his ability to enroll powerful people into his projects through his mats and by acceding shrewdly to the relations and ideas specified within the heterotopia, had, as he once put it, shown Ali that just winning an award was not enough.

\section{Conclusion}

In the latter half of the twentieth century, writes Foucault, 'our experience of the world is less that of a long life developing through time than that of a network that connects 
points and intersects with its own skein' (1986 [1967]:22). This generates a particular kind of heterotopia. The connecting on the basis of utopian visions of diverse entities combined with the reflexive nature of the skein that intersects itself makes the heterotopia a good way to think through the puzzle posed at the beginning of the article: the bringing to the centre from the margins of people and things that are emblems for powerful others.

In traditional Indian craft, relations between selected things and persons are specified by powerful elites who seek to realize certain utopian visions. These utopian visions are what make certain marginalized people and things romanticized as valued anachronisms and as differently contemporary. As craft objects and craft producers, things and persons acquire the ability to make things happen in the social world. As we saw, the mat for the Queen transformed the mat-weavers of Pattamadai into craft producers. It brought them and their manufactures into the social space of traditional Indian craft, making both able to act. However, the agency exercised by persons and things is not equivalent. This is not just due to the question of intentionality. Craft objects are able to access more social spaces than their producers. They enchant receptive people in these social spaces. This quality makes them potentially transformative; it certainly makes them active. But both persons and things are highly circumscribed, as was seen in the discussion about Beevi's award-winning mat. Even as national award-winners, Beevi and Ali do not change the terms on which they are accepted and supported by the craft world.

The heterotopia of craft is based on resistance to a totalizing industrialization, but the craft producers at its centre are not resisting industrialization or the mass-production of commodities. Indeed, many women in Pattamadai prefer rolling leaf cigarettes for the many companies in the region. This work, though household industry and handwork, is not identified by the craft world as craft activity. Young men would rather, if their households could afford it, go on to higher education, taking diplomas in automobile engineering and working in one of the many car factories that are located in Tamilnadu. But they do not necessarily have these choices and, like their fathers, can either take to petty trading or work as unskilled labour migrants if they do not want to weave mats. They may also put themselves forward as craft producers. Few young men, however, take this route, preferring to try their hand at other things. Their attitude reflects the general feeling in Pattamadai about being a mat-weaver/craft producer.

Saba Mahmood (2001) suggests that rather than thinking about agency as resistance, we focus on how it is a capacity for action that is enabled and created by historically specific relations of subordination. Mantri and Beevi have learned how they and their things can be agentive within the heterotopia by submitting to its rules and idealizations and by letting their mats as well as powerful others act on their behalf. Ali's inability or unwillingness to be strategically docile meant that his agentive capacities within the heterotopia were lost. Not submitting to, or performing, its idealization of him, Ali fell out of the heterotopia. But this does not mean that he cannot act effectively anywhere else. The heterotopia is only one social space among others that Ali, like other craft producers, encounters.

For Foucault, the mirror is a good way to think about heterotopias. The mirror shows something that is both here and not here. It permits juxtapositions and projections. The heterotopia of traditional Indian craft is made up of a large network that connects manufacturing processes, things, artisans, traders, craft developers, the nation, the world, the past, the present, the market, the home, the ritual space, and the public space. Craft is the mirror through which this network sees itself. And just outside its frame continue all the concerns that press upon the different people who are gazing 
into it. The various points that make up the network of traditional Indian craft are not necessarily compatible. Nor do they function outside the particular historical moment that is India today with its material and human resources, its hierarchies, inequalities, the colonial past and post-colonial present, and the ideological, pragmatic, and other concerns that drive various people.

While I have restricted my comments to traditional Indian craft, which is underpinned by its own specific utopian visions and its historical conditions of existence, I want to make a few general points about heterotopias such as traditional Indian craft that might be of wider value, especially when thinking about the partial objectification of persons who are celebrated within these visions.

Heterotopias produce social categories by placing entities in new relations with each other. This point is not straightforward and demands analysis.

A particular type of personhood is defined by ideas informing the heterotopia. This personhood may not look different from larger ideas of personhood but may function differently. Indian craft producers, for instance, are synthesized with their manufactures and the processes they employ. This echoes how personhood within the caste framework is conceptualized. However, the ideological underpinnings and effects of this within the heterotopia work very differently to caste.

Inhabitants of the heterotopia's social categories take their forms and properties from the ideas and practices that underpin it - they are products of the relations specified within the heterotopia. This does not mean that they are unrecognizable from other contexts, merely that they are re-created as new social beings with specific agentive capacities.

While my article takes traditional Indian craft as its main focus, I adopt Foucault's rather bold point that ' $\mathrm{t}$ ] here is probably not a single culture in the world that fails to constitute heterotopias' (1986 [1967]: 24). Therefore the discussion in this article, while specific to one heterotopia, is intended to be of wider use in comparative anthropology - especially, though not only, when asking questions about personhood, agency, power, and the role of utopian visions and social categories in agent creation.

\section{NOTES}

Matei Candea, Nina Glick-Schiller, Sarah Green, Chris Gregory, Penny Harvey, Jennifer Morgan, Atreyee Sen, Jessica Symons, and Jonathan Woolf generously read and commented on versions of this article. The Social Anthropology seminars at Brunel and Kent gave valuable feedback. My thanks to them. I would also like to thank the editor of JRAI and anonymous reviewers. Finally, my unbounded gratitude to the people of Pattamadai and members of craft development agencies, who were both patient and generous.

${ }^{1}$ Following Becker's (1982) discussion of the art world (also see Bundgaard 1999).

${ }^{2}$ Birdwood's lyrical (and implausible) evocation of Indian village crafts may be found in his 1880 work (esp. 58-9).

3 'The [Indian] craftsman is not an individual expressing individual whims, but a part of the universe, giving expression to ideals of eternal beauty and unchanging laws, even as do the trees and flowers whose natural and less ordered beauty is no less God-given' (Coomaraswamy 1909: 75). This quote continues to be commonly cited, e.g. GOI (1999); Chari (1998).

${ }^{4}$ Gandhi paraphrased the essay in Gujarati under the title Sarvodaya, or 'progress for all' (1956 [1908]). It should be noted that Gandhi and Ruskin completely diverged in their respective attitudes to British imperialism (see Brantlinger 1996).

${ }^{5}$ Historical studies (e.g. Bean 1999; Roy 1996) show that not all industries identified as craft suffered from industrialization or during the colonial period. Indeed, a Pattamadai mat was included, and won a medal, in an exhibition organized by the colonial government (Watt 1904). However, like Gottschalk (2001: 72), I do not want to privilege 'history' over 'myth', focusing instead on what 'mythic' narratives do.

${ }^{6}$ For instance, in the Festivals of India held in several countries. 


\section{SOUMHya Venkatesan}

${ }^{7}$ The Confederation of Indian Industry, for example, funded an NGO to develop selected rural traditional crafts as a way of stemming migration of producers to cities.

${ }^{8}$ See Greenough (1995); also Liebl \& Roy (2003) for the problems in calculating numbers of artisans.

${ }^{9}$ Email, Melanie Edwards, Inventory Clerk for the London Palaces and residences, 9 August 2005.

${ }^{10}$ Similarly, development practitioners who work closely and directly with producers are less prone to romanticism. But they may have to employ the heterotopia's discursive flourishes, especially when engaging with markets and funders.

${ }^{11}$ Ministry of Textiles, Press Release, 22 May 1999.

${ }^{12}$ The name of the town is unchanged; all person's names (except Mr. V.A.K. Rangan's) are pseudonyms.

${ }^{13}$ Four years later, a weaver submitted a mat for the awards competition. Anamika did not feel she could support this mat as it featured a representational image. It did not fit her image of the 'authentic' Pattamadai mat.

${ }^{14}$ Ali's award had the effect of encouraging other weavers to work with the NGO.

${ }^{15}$ The letter neglects to mention the late nineteenth- or early twentieth-century origin of the high-quality mats of Pattamadai.

${ }^{16}$ I did not see this letter, but was told about it by Ali.

${ }^{17}$ While Beevi's letter does employ flattery, especially in the way in which the recipient is characterized as benevolent and powerful, it is less clear that it is an example of coercive subordination of the kind so well analysed by Staples (2003) in his discussion of leper-beggars. Unlike the leper-beggars and similar subordinate groups, successful asking by craft producers foregrounds their production of objects valued by those whom they approach, which in turn makes the producers valued.

\section{REFERENCES}

BEAN, S. 1999. The art of clay sculpture in Bengal. In Maker and meaning: craft and society, 98-111. Dakshinachitra, Madras: Madras Craft Foundation.

Becker, H.S. 1982. Art worlds. Berkeley: University of California Press.

Birdwood, G.M. 1880. The industrial arts of India. London: Chapman \& Hall.

Brantlinger, P. 1996. A postindustrial prelude to postcolonialism: John Ruskin, William Morris, and Gandhism. Critical Enquiry 22, 466-85.

BUNDGAARD, H. 1999. Indian art worlds in contention: local, regional and national discourses on Orissan Patta paintings. Richmond, Surrey: Curzon.

Chari, P. 1996. The wonder of the Pattamadai mat. The Hindu, 25 February. Madras. 1998. Weaving craft into dance. The Hindu, 15 February. Madras.

Chattopadhyay, K. 1980. India's craft tradition. New Delhi: Publications Division, Government of India. Coomaraswamy, A.K. 1909. The Indian craftsman. London: Probsthain.

Durrans, B. 1982. Handicrafts, ideology and the Festival of India. South Asia Research 2, 13-22.

Foucault, M. 1986 [1967]. Of other spaces (trans. J. Miskowiec). Diacritics 16: 1, 22-7.

Gandhi, M.K. 1956 [1908]. Sarvodaya (trans. V.G Desai). Ahmedabad: Navjivan.

Gell, A. 1998. Art and agency. Oxford: Clarendon Press.

GOI (Government of India) 1998. Compendium of handicraft schemes. Office of the Development Commissioner (Handicrafts).

1999. National awards for master craftspersons and weavers, 1996 and 1997. Office of the Development Commissioner (Handicrafts).

Goswami, M. 2004. Producing India: from colonial economy to national space. Delhi: Permanent Black.

Gottschalk, P. 2001. Beyond Hindu and Muslim: multiple identity in narratives from village India. Delhi: Oxford University Press.

Greenhalgh, P. 1997. The history of craft. In The culture of craft (ed.) P. Dormer, 20-52. Manchester: University Press.

Greenough, P. 1995. Nation, economy and tradition displayed: the Indian Crafts Museum, New Delhi. In Consuming modernity: public culture in a South Asian world (ed.) C.A. Breckenridge, 216-48. Minneapolis: University of Minnesota Press.

Havell, E.B. 1986 [1912]. The basis for artistic and industrial revival in India. Delhi: Usha.

LAIDLAW, J. 2002. For an anthropology of ethics and freedom. Journal of the Royal Anthropological Institute (N.S.) 8, 311-32.

Latour, B. 2005. Reassembling the social: an introduction to Actor-Network-Theory. Oxford: Oxford University Press.

Liebl, M. \& T. Roy 2003. Handmade in India. Economic and Political Weekly 38, 5366-76. 
Mahmood, S. 2001. Feminist theory, embodiment and the docile agent: some reflections on the Egyptian Islamic revival. Cultural Anthropology 16, 202-36.

Mitter, P. 1994. Art and nationalism in colonial India, 1850-1922: occidental orientations. Cambridge: University Press.

Muthahar, S. 1995. University bid to revive dying skill. In The Hindu, 23 November. Madras.

Nambiar, P.K. 1964. Fine mats of Pattamadai. Madras: Census of India 1961(IX): part VII-A-IV (handicrafts and artisans of Madras State).

Roy, T. 1996. Home market and the artisans in colonial India: a study of brass-ware. Modern Asian Studies 30, $357-85$.

Ruskin, J. 1987 [1862]. Unto this last. In Unto this last and other writings (ed. C. Wilmer), 155-228. London: Penguin.

Staples, J. 2003. Disguise, revelation and copyright: disassembling the South Indian leper. Journal of the Royal Anthropological Institute (N.S.) 9, 295-315.

Symons, J. 2007. Utopian visions, dream bridges and the disruption of capitalism. MA dissertation. University of Manchester.

TARLO, E. 1996. Clothing matters: dress and identity in India. London: Hurst.

Venkatesan, S. 2006. Shifting balances in a 'craft community': the mat-weavers of Pattamadai, South India. Contributions to Indian Sociology (N.S.) 40, 63-89.

- in press. Craft Matters: Indian artisans, 'development' and the nation. Delhi: Orient BlackSwan.

WatT, G. 1904. Indian art at Delhi 1903, being the official catalogue of the Delhi exhibition, 1902-1903. London: John Murray.

\section{Repenser l'agency : Personnes et objets dans l'hétérotopie de «l'artisanat indien traditionnel »}

Résumé

Sur la base d'un travail d'ethnographie parmi les tisserands de tapis handloom d'Inde du Sud, l'auteur s'interroge sur la façon dont les personnes et les objets deviennent des agents et sur ce qu'implique ce processus. Le concept d'hétérotopie de Foucault est mis à contribution pour résoudre l'énigme de «l'artisanat indien traditionnel », sans toutefois s'y limiter : pourquoi et comment certaines personnes et certains objets marginalisés sont-ils amenés par d'autres, plus puissants, au centre d'un espace social encadré? Comment ce repositionnement accroît-il et restreint-il à la fois la capacité d'agir efficacement de ces personnes et de ces objets? L'article propose également une approche de la réflexion sur les objets agissants, tout en évitant l'écueil de l'intentionnalité.

Soumhya Venkatesan is a lecturer in Social Anthropology at the University of Manchester. Following a BA in History (Madras University) and an MA in the History of Art (National Museum, Delhi), she has found her disciplinary home in social anthropology. This article is based on her doctoral work (Cambridge, 2002). Soumhya conducted research in Pattamadai for varying periods of time between 1995 and 2003.

Social Anthropology, University of Manchester, Arthur Lewis Building, Manchester M13 9PL, UK. Soumhya.Venkatesan@manchester.ac.uk 